\title{
TWO NEW ANTS'-NEST COCCIDS FROM TEXAS.
}

BY GEO. B. KING, LAWRENCE, MASS.

Dactylopius Wheeleri, n. sp. $-q$ flesh colour, covered with a white, fluffy material, elongate oval, $13 / 4 \mathrm{~mm}$. long, I broad, $1 / 2 \mathrm{high}$, convex, very flat beneath. Segmentation distinct. Boiled in potash, they turn brown; transferred to cold water, the internal juice becomes colourless. Pressed under cover-glass, the skin is colourless, with several long hairs anteriorly and on the caudal region above the anal ring and caudal tubercles. Anal ring normal, with six stout bristles. Caudal tubercles very prominent, with two long bristles $\mathrm{I} 20$ and $260 \mu$ long. Legs stout, front leg coxa I40. Femur and trochanter 220. Tibia 148 . Tarsus roo $\mu$ long. Claw thin, sharp, with a distinct tooth near the end. Tibia and tarsus have several short hairs. Digitules of tarsus and claw very small. Labium small. Rostral loop exceedingly long.

Antennæ 7 -jointed: Joint (I) $48,(2) 52,(3) 5^{2},(4) 44,(5) 40,(6)$ 40 , (7) roo. Formula $7(23) \times 4\left(5^{6}\right)$ of a finished mount in balsam. The same examples measured, while they were wet with alcohol under cover-glass, as follows: Joint (I) 40, (2) 60, (3) 44, (4) 44, (5) 44, (6) 44 , (7) 104. Formula 72(3456) I. All the joints have several short hairs, excepting joint 7 , which has two long hairs at the tip of that joint. Antennæ 2 I $6 \mu$ apart. Eyes large, oval.

Hab.-Austin, Texas, in nests of Camponotus maculatus, var. sansabeanus, Buckley. Collected and sent to me for study by Prof. William M. Wheeler, of the University of Texas, who says the ants remove the coccids to their chambers when the nests are disturbed, and that they are very frequently met with. I have given the measurements of the several joints of the antennæ while wet and hardened in alcohol and a finished mount in balsam, for the purpose of calling attention to the variability of the antennal joints under each process. Owing to our large list of Coccidæ now described, it seems to the writer that all such changes should be recorded, so as to assist in every way possible the identification of the species if found in another locality or country. This is the first ant-nest coccid from Texas, and the first species of the genus Camponotus found in North America to harbour coccids in its nest. 
Eriococcus Texamus, n. sp.-The females of this species received from Prof. Wheeler were in alcohol, and seemed to be flesh colour; when placed in liquid potash, they turn red-brown. "When alive, they are of a peculiar green colour" (Wheeler).

$q$, examined with a hand lens, very much resembling a Dactylopius naked, i. e., without ovisac, distinctly segmented, oval, tapering behind, plump, $21 / 2 \mathrm{~mm}$. long, $13 / 4$ broad. Boiled in K. O. H., the derm is tinged with yellow, with spines of the normal type and confined to sides, short, $20 \mu$ long, those of the outer margin twice as long; several spirre-like long hairs of two sizes are found scattered irregularly over the body, $28 \times 60 \mu$ long, and some round gland-pits. Antennæ, legs and mouth-parts light brown. Antennæ 6-jointed: Joints (I) 40, (2) 40, (3) I I $2,(4) 28$, (5) 28 , (6) $40 \mu$ long.

Legs long and stout.

Front leg coxa, r20. Femur and trochanter 200. Tibia I 20 . Tarsus 132.

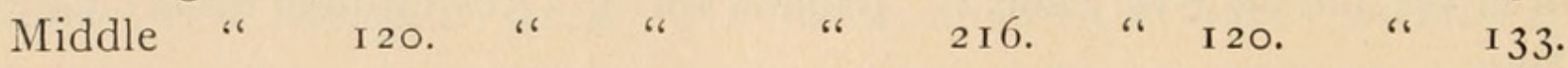
Hind " I80. " " " Claws $6 \mu$ long, stout, curved and thin towards the end. Digitules of tarsus filiform, with small knobbed ends. Anal ring normal, with 8 bristles, which are thin, 100 $\mu$ long. Posterior tubercles large and rounded, about $80 \mu$ long and broad, with one long bristle and four stout spines $24 \mu$ long.

Hab.-San Angelo, Texas, on roots or young shoots in the earthen nests of Cremastogaster punctulata, Emery. "They were undoubtedly being cultivated by the ants" (Wheeler). Collected by Prof. Wheeler, March, 1902. Its nearest North American ally is Eriococcus Tinsleyi, Ckll., which has in the hind leg a very long tarsus as in E. Texanus, but differs very materially in other respects; in the antennæ a general type of E. Palmeri, Ckll., but in Texanus joint 3 is very much longer than in Palmeri.

This is the first species of the genus Eriococcus known to inhabit ants' nests. The absence of an ovisac in this species is no doubt due to the habit of the ants lapping the bodies of the coccids, and thus preventing a sac from forming. In a recent letter from Prof. Cockerell, he says: "If this really has no ovisac, even when producing eggs, it is not an Eriococcus, but a Rhizococcus. Such forms occur in Australia, and Signoret recorded one from Europe. Rhizococcus is to Eriococcus as Calymnatus is to Pulvinaria." 


\section{$2 \mathrm{BHL}$ Biodiversity Heritage Library}

King, G B. 1902. "Two new ants'-nest coccids from Texas." The Canadian entomologist 34, 285-286. https://doi.org/10.4039/Ent34285-11.

View This Item Online: https://www.biodiversitylibrary.org/item/18808

DOI: https://doi.org/10.4039/Ent34285-11

Permalink: https://www.biodiversitylibrary.org/partpdf/3630

\section{Holding Institution}

MBLWHOI Library

\section{Sponsored by}

MBLWHOI Library

\section{Copyright \& Reuse}

Copyright Status: NOT_IN_COPYRIGHT

This document was created from content at the Biodiversity Heritage Library, the world's largest open access digital library for biodiversity literature and archives. Visit BHL at https://www.biodiversitylibrary.org. 